\title{
Spectroscopic, Structural Studies, Fluorescence and Optical Properties of Group VI Dinuclear Derivatives of $\mathrm{N}_{2} \mathrm{O}_{2}$ Schiff Base
}

\author{
Aml A. A. Awad, Doaa A. Nassar", Omyma A. M. Ali \\ Chemistry Department, Faculty of Women for Arts, Science and Education, Ain Shams University, Cairo, Egypt.
}

*Corresponding Author: Doaa A. Nassar, Chemistry Department, Faculty of Women for Arts, Science and Education, Ain Shams University, Cairo, Egypt.

\begin{abstract}
Reaction of $M(C O)_{6}(M=C r$, Mo and $W)$ with $6,6^{\prime}\left(\left(\left[1,1^{\prime}\right.\right.\right.$ biphenyl]4, 4'diylbis (azaneylylidene $\left.)\right)$ bis (methaneylylidene)) bis(2,4-dichlorophenol) $\mathrm{H}_{2} L$ in THF were investigated. Under Sunlight irradiation, dinuclear carbonyl chromium complex $\left[\mathrm{Cr}_{2}(\mathrm{CO})_{2} \mathrm{~L}_{2}\right]$ and two dinuclear oxo complexes $\left[\mathrm{Mo}_{2} \mathrm{O}_{4} \mathrm{~L}_{2}\right]$ and $\left[\mathrm{W}_{2} \mathrm{O}_{4} \mathrm{~L}_{2}\right]$ were isolated. In air, the corresponding reaction with $\mathrm{Mo}(\mathrm{CO})_{6}$ produced the dinuclear carbonyl oxo complex $\left[\mathrm{Mo}_{2} \mathrm{O}_{5}(\mathrm{CO}) L\right]$. H2O. All complexes were characterized by elemental analysis, IR, mass and ${ }^{l} \mathrm{H}$ NMR spectroscopy. Magnetic studies for $\left[\mathrm{Mo}_{2} \mathrm{O}_{4} \mathrm{~L}_{2}\right],\left[\mathrm{W}_{2} \mathrm{O}_{4} \mathrm{~L}_{2}\right]$ and $\left[\mathrm{Mo}_{2} \mathrm{O}_{5}(\mathrm{CO}) \mathrm{L}\right] . \mathrm{H}_{2} \mathrm{O}$ complexes showed diamagnetic characteristics. TG-DTG study was done to track the thermal behavior of the complexes and the thermodynamic parameters were computed from the thermal data using Coats-Redfern and Horowitz-Metzger methods. The ultraviolet-vis spectra of the complexes in DMSO showed broad bands due to ligand-to-metal charge transfer. The fluorescence spectra of these complexes indicate the luminescence characteristics of the complexes. The values of optical band gap energy $\left(E_{g}\right)$ of the synthesized complexes suggested that these compounds could be used as semiconductors.
\end{abstract}

Keywords: Benzidine; Carbonyl; Complexes; Fluorescence; Optical Properties

\section{INTRODUCTION}

Schiff bases metal complexes containing nitrogen and oxygen donor atoms play an important role in an enormous number of publications, ranging from pure synthetic work to physicochemical [1] and biochemically relevant studies of metal complexes [2]. They also use as photo-sensitizers, catalysts and conducting coordinating polymers $[3,4,5]$ and found wide range of applications $[6,7]$. On the other hand, carbonyl complexes are useful intermediates in the synthesis of important coordination compounds $[8,9,10]$. In addition, metal carbonyl complexes are of considerable structural interest as well as of industrial, catalytical importance, epoxidation reactions, catalytic activity in hydrogenation of olefines and photochromic properties [11,12]. Schiff bases containing nitrogen and oxygen donor atoms such as

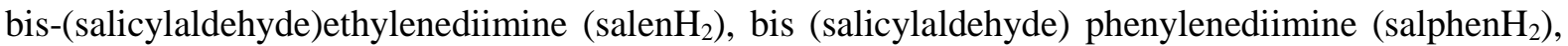
salicylideneimine-2-anisole (salanH), N-salicylidene-2-hydroxyaniline $\left(\mathrm{shaH}_{2}\right)$, 2,4-dichloro-5Fluorophenyl and derivatives of benzimidazole, thiazole, pyridine, pyrazolone, hydrazine, pfluorobezaldehyde are useful for the synthesis of transition metal complexes which play important role in biological systems $[13,14,15,16,17,18]$.

Our interest in investigation of the reactions of metal carbonyls with Schiff bases has prompted us to investigate the reactions of $\mathrm{M}(\mathrm{CO})_{6}\left(\mathrm{M}=\mathrm{Cr}\right.$, Mo and W) with Schiff base $\left(\mathrm{H}_{2} \mathrm{~L}\right)$ derived from 3,5dichlorosalicylaldehyde and benzidine.

\section{EXPERIMENTAL}

\subsection{Materials}

$\mathrm{M}(\mathrm{CO})_{6}, \mathrm{M}=\mathrm{Cr}$, Mo and $\mathrm{W} ; 3$,5-Dichlorosalicylaldehyde and benzidine were supplied from Aldrich. All the chemicals were of analytical reagent grade and used without purification

\subsection{Instrumentation}

Carbon, hydrogen and nitrogen $(\mathrm{C}, \mathrm{H} \& \mathrm{~N})$ analyses were carried out on a Perkin- Elmer 2400 mode instrument. IR spectra were recorded using $\mathrm{KBr}$ pellets in the region $4000-400 \mathrm{~cm}^{-1}$ on FTIR spectrophotometer, Shimadzu 8201. The ${ }^{1} \mathrm{H}$ NMR spectra was recorded by using DMSO as a solvent 
and a BRUKER $500 \mathrm{MHz}$ spectrophotometer using TMS as an internal reference. Mass spectrometry measurements of the solid ligand and its complexes were measured on a JEOL JMS-AX 500 spectrometer. The TG and DTG analysis were recorded with a heating rate of $10{ }^{\circ} \mathrm{C} / \mathrm{min}$ under a nitrogen atmosphere using a Shimadzu DT-50 thermal analyzer. The ligand and its complexes spectra were measured on a Shimadzu $3101 \mathrm{pc}$ spectrophotometer. The photoluminescent properties of all the compounds were studied using a LS50B Jenway 6270 Fluorimeter.

\subsection{Synthesis of the Schiff base 6,6'-(([1,1'-biphenyl]-4,4'-diylbis(azaneylylidene))bis(methaneylylid- ene))bis(2,4-dichlorophenol) $\left(\mathrm{H}_{2} \mathrm{~L}\right)$}

Schiff base ligand $\left(\mathrm{H}_{2} \mathrm{~L}\right)$ was prepared by dissolving $0.38 \mathrm{~g}(2 \mathrm{mmol})$ of 3,5-di-chlorosalicylaldehyde and $0.18 \mathrm{~g}(1 \mathrm{mmol})$ of benzidine in methyl alcohol. This mixture was stirring at room temperature for 1h. Orange precipitate was formed, filtrated off and washed several times with methanol and then left to dry at room temperature (Scheme 1).

\subsection{Synthesis of Complexes}

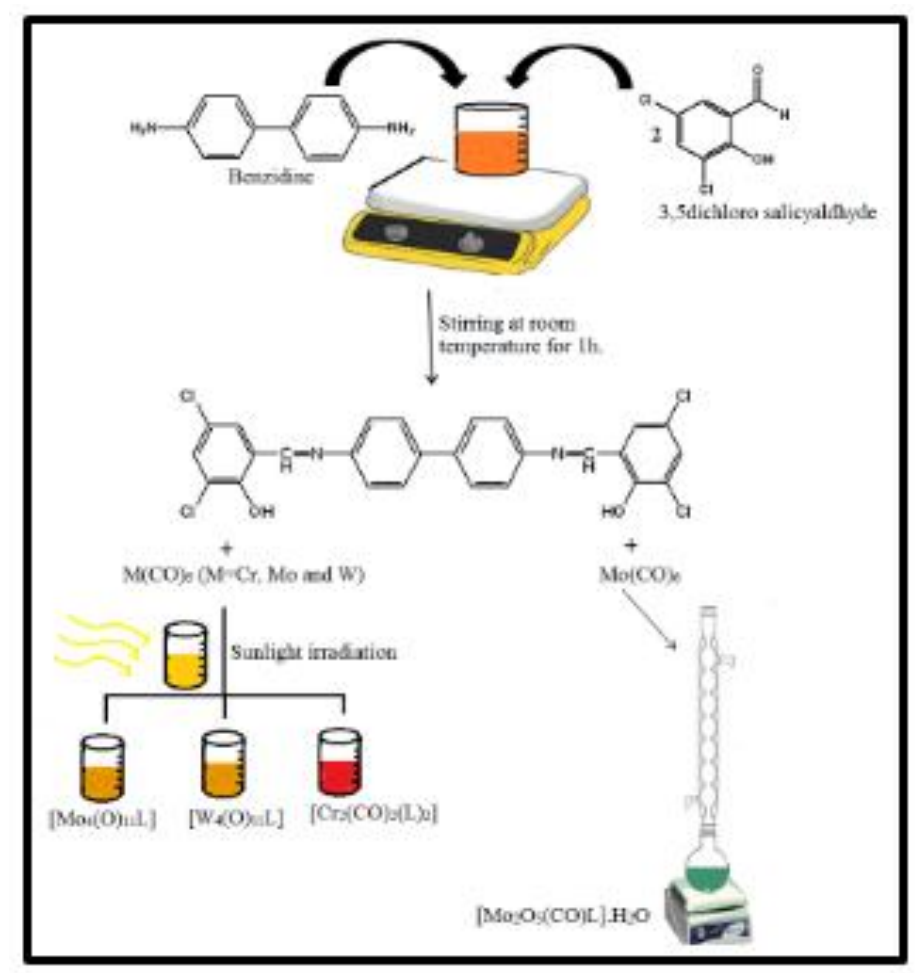

Scheme1. Synthesis of the ligand and its $\mathrm{Cr}$, Mo and $\mathrm{W}$ complexes

\subsubsection{Synthesis of $\left[\mathrm{Cr}_{2}(\mathrm{CO})_{2} \mathrm{~L}_{2}\right],\left[\mathrm{Mo}_{2} \mathrm{O}_{4} \mathrm{~L}_{2}\right]$ and $\left[\mathrm{W}_{2} \mathrm{O}_{4} \mathrm{~L}_{2}\right]$ Complexes}

A mixture of $\left[\mathrm{M}(\mathrm{CO})_{6}\right], \mathrm{M}=\mathrm{Cr}$, Mo and $\mathrm{W}$, and ligand in equimolar ratio in $30 \mathrm{ml}$ THF was exposed to sunlight irradiation for $24 \mathrm{~h}$. The solvent was evaporated and the precipitate was isolated. The precipitate washed several times by hot petroleum ether (Scheme 1).

\subsubsection{Synthesis of $\left[\mathrm{Mo}_{2} \mathrm{O}_{5}(\mathrm{CO}) \mathrm{L}\right] \cdot \mathrm{H}_{2} \mathrm{O}$ complex}

A mixture of $\mathrm{Mo}(\mathrm{CO})_{6}(0.17 \mathrm{~g}, 0.2 \mathrm{mmol})$ and ligand $(0.05 \mathrm{~g}, 0.1 \mathrm{mmol})$ in $30 \mathrm{ml} \mathrm{THF}$ was heated to reflux in air for $6 \mathrm{~h}$. The color of the mixture was changed from orange to dark green with the formation of the precipitate. The solvent was evaporated. The isolated precipitate was washed several times by hot petroleum ether (Scheme 1).

\section{RESULTS AND DISCUSSION}

Physicochemical, elemental analyses and mass spectrometry data of the prepared Cr, Mo and $\mathrm{W}$ solid complexes of the Schiff base $\left(\mathrm{H}_{2} \mathrm{~L}\right)$ were summarized in Table 1. The data are in good agreement with the proposed structures of the complexes. The metal complexes were colored and stable towards air and moisture at room temperature. They were insoluble in common organic solvents (methanol, ethanol, acetone and chloroform), but soluble in dimethylformamide (DMF) and dimethylsulfoxide (DMSO). 
Spectroscopic, Structural Studies, Fluorescence and Optical Properties of Group VI Dinuclear Derivatives of $\mathrm{N}_{2} \mathrm{O}_{2}$ Schiff Base

Table1. Physical properties and analytical data of the Schiff base ligand $\left(\mathrm{H}_{2} \mathrm{~L}\right)$ and its metal carbonyl complexes.

\begin{tabular}{|c|c|c|c|c|c|c|c|c|}
\hline \multirow[t]{2}{*}{ Compound } & \multirow[t]{2}{*}{ Color } & \multirow[t]{2}{*}{$\begin{array}{c}\text { Yield } \\
\%\end{array}$} & \multirow[t]{2}{*}{ M.P. } & \multicolumn{3}{|c|}{$\begin{array}{l}\text { Elemental analysis } \\
\text { Found (calc.) }\end{array}$} & \multicolumn{2}{|c|}{$\begin{array}{c}\text { Mass } \\
\text { Spectrometry }\end{array}$} \\
\hline & & & & $\mathrm{C} \%$ & $\mathrm{~N} \%$ & $\mathrm{H} \%$ & Mol.Wt. & $\mathrm{m} / \mathrm{z}$ \\
\hline $\mathrm{H}_{2} \mathrm{~L}\left(\mathrm{C}_{26} \mathrm{H}_{16} \mathrm{~N}_{2} \mathrm{O}_{2} \mathrm{Cl}_{4}\right)$ & orange & 87 & 260 & $\begin{array}{c}58.96 \\
(58.89)\end{array}$ & $\begin{array}{c}5.39 \\
(5.28)\end{array}$ & $\begin{array}{c}3.12 \\
(3.04)\end{array}$ & 530.21 & $531\left(\mathrm{P}^{+}\right)$ \\
\hline $\mathrm{Cr}_{2} \mathrm{C}_{54} \mathrm{H}_{28} \mathrm{~N}_{4} \mathrm{O}_{6} \mathrm{Cl}_{8}$ & red & 46 & $>300$ & $\begin{array}{c}52.23 \\
(52.32)\end{array}$ & $\begin{array}{c}4.43 \\
(4.60)\end{array}$ & $\begin{array}{c}2.31 \\
(2.32)\end{array}$ & 1216.41 & $\begin{array}{c}1160 \\
\left(\mathrm{P}^{+}-2 \mathrm{CO}\right)\end{array}$ \\
\hline $\mathrm{Mo}_{2} \mathrm{C}_{52} \mathrm{H}_{28} \mathrm{~N}_{4} \mathrm{O}_{8} \mathrm{Cl}_{8}$ & brown & 50 & $>300$ & $\begin{array}{c}47.76 \\
(47.59)\end{array}$ & $\begin{array}{c}4.67 \\
(4.26)\end{array}$ & $\begin{array}{c}2.21 \\
(2.15)\end{array}$ & 1312.27 & $1312\left(\mathrm{P}^{+}\right)$ \\
\hline $\mathrm{W}_{2} \mathrm{C}_{52} \mathrm{H}_{28} \mathrm{~N}_{4} \mathrm{O}_{8} \mathrm{Cl}_{8}$ & brown & 45 & $>300$ & $\begin{array}{c}41.71 \\
(41.69)\end{array}$ & $\begin{array}{c}3.82 \\
(3.76)\end{array}$ & $\begin{array}{c}1.86 \\
(1.98)\end{array}$ & 1488.03 & $1488\left(\mathrm{P}^{+}\right)$ \\
\hline $\mathrm{Mo}_{2} \mathrm{C}_{27} \mathrm{H}_{16} \mathrm{~N}_{2} \mathrm{O}_{9} \mathrm{Cl}_{4}$ & $\begin{array}{l}\text { Dark } \\
\text { green }\end{array}$ & 65 & $>300$ & $\begin{array}{c}38.84 \\
(38.33)\end{array}$ & $\begin{array}{c}3.21 \\
(3.31)\end{array}$ & $\begin{array}{c}1.89 \\
(1.90)\end{array}$ & 846.01 & $846\left(\mathrm{P}^{+}\right)$ \\
\hline
\end{tabular}

The significant infrared bands of the prepared Schiff base ligand and its metal complexes were summarized in Table 2\& Figure 1. Infrared spectrum of the ligand showed a broad band at $3384 \mathrm{~cm}^{-1}$ which can be attributed to phenolic $\mathrm{OH}$ group [19]. This band disappeared in all complexes, indicating the coordination of $\mathrm{H}_{2} \mathrm{~L}$ oxidatively to metal with proton displacement. The free Schiff base ligand showed a strong band at $1615 \mathrm{~cm}^{-1}$, which was characteristic of the azomethine $(-\mathrm{HC}=\mathrm{N})$ group [20]. On complexation, this band was shifted to lower or higher frequencies indicating the coordination of the ligand to metal through azomethine nitrogen atoms [21,22]. Also, the C-O stretching band of the free $\mathrm{H}_{2} \mathrm{~L}$ was shifted to a higher frequency range indicating coordination through the phenolic oxygen [23]. In the IR spectra of all complexes, the non-ligand bands observed in range from 574 to $590 \mathrm{~cm}^{-1}$ due to $\mathrm{M}-\mathrm{O}$ and from 473 to $493 \mathrm{~cm}^{-1}$ for $\mathrm{M}-\mathrm{N}$ bonds [24]. The IR spectrum of $\left[\mathrm{Cr}_{2}(\mathrm{CO})_{2}(\mathrm{~L})_{2}\right]$ complex showed strong band at $1718 \mathrm{~cm}^{-1}$ due to bridging carbonyl group [25]. On the other hand, the IR spectrum of $\left[\mathrm{Mo}_{2} \mathrm{O}_{5}(\mathrm{CO}) \mathrm{L}\right] \cdot \mathrm{H}_{2} \mathrm{O}$ complex exhibited two bands at 1718 and $627 \mathrm{~cm}^{-1}$ due to bridging carbonyl group and Mo-O-Mo bridged bond, respectively [26]. In addition, the IR spectrum of molybdenum complex displayed stretching vibrational band of hydrated water and symmetric and asymmetric stretching frequencies of terminal $\mathrm{Mo}=\mathrm{O}$ bonds for a cis $\mathrm{MO}_{2}$ fragment [27,28]. The IR spectra of the two oxo complexes $\left[\mathrm{Mo}_{2} \mathrm{O}_{4}\left(\mathrm{~L}_{2}\right)\right]$ and $\left[\mathrm{W}_{2} \mathrm{O}_{4}\left(\mathrm{~L}_{2}\right)\right]$ showed the two terminal $\mathrm{Mo}=\mathrm{O}$ vibrations at $915-906 \mathrm{~cm}^{-1}$ and $886-937 \mathrm{~cm}^{-1}[29]$.

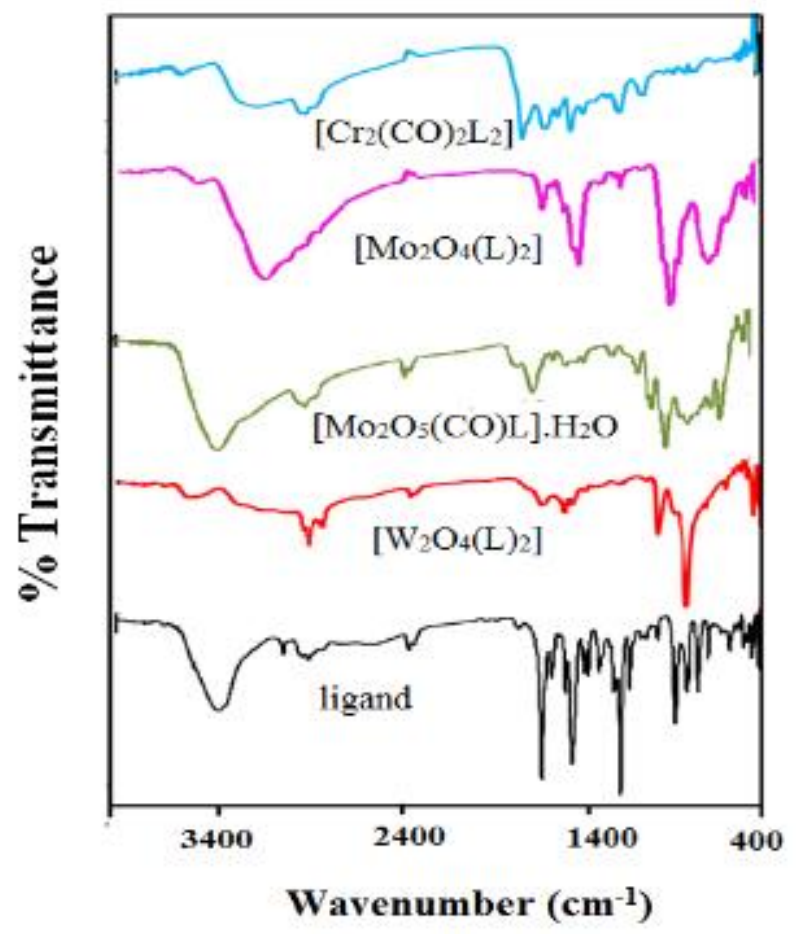

Figure1. IR spectra of the Schiff base ligand and its complexes 


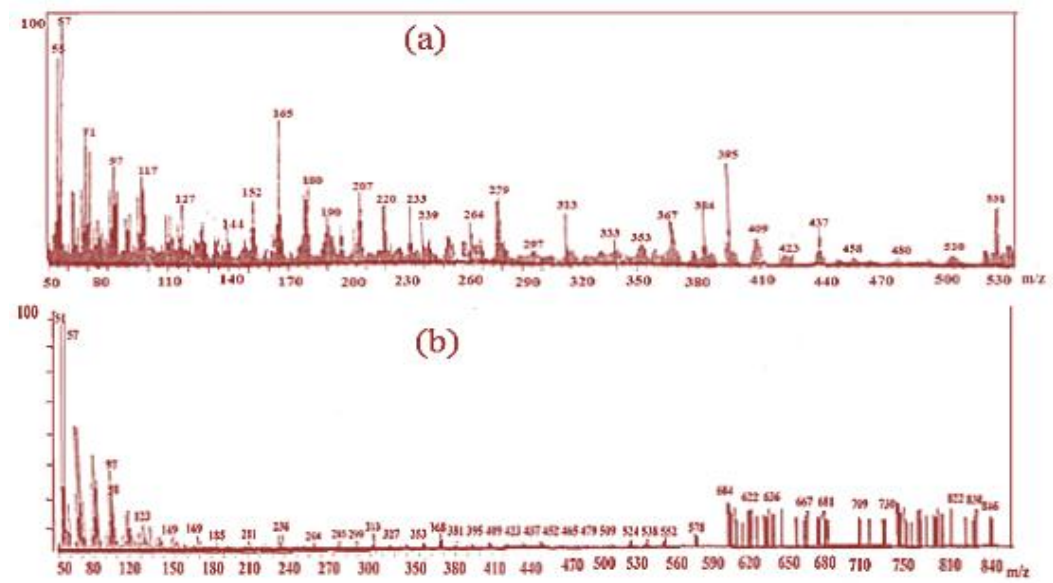

Figure2. The mass spectra of (a) ligand $\left(\mathrm{H}_{2} \mathrm{~L}\right)$ and $(b)\left[\mathrm{Mo}_{2} \mathrm{O}_{5}(\mathrm{CO}) \mathrm{L}\right] \cdot \mathrm{H}_{2} \mathrm{O}$ complex

Table2. Most important IR spectral bands of the ligand and its complexes

\begin{tabular}{|c|c|c|c|c|c|c|c|c|}
\hline \multirow{2}{*}{ Compound } & \multicolumn{9}{|c|}{ IR spectra $\left(\mathrm{cm}^{-1}\right)$} \\
\cline { 2 - 9 } & $\begin{array}{c}v(\mathrm{OH}) \\
/\left(\mathrm{OH}_{2}\right)\end{array}$ & $v(\mathrm{C}=\mathrm{N})$ & $\begin{array}{c}v(\mathrm{C}- \\
\mathrm{O})\end{array}$ & $v \mathrm{M}=\mathrm{O}$ & $\begin{array}{c}\text { vM-O- } \\
\mathrm{M}\end{array}$ & $\begin{array}{c}\text { vM-CO- } \\
\mathrm{M}\end{array}$ & $\begin{array}{c}v \mathrm{M}-\mathrm{O} \\
v \mathrm{M}- \\
\mathrm{N}\end{array}$ \\
\hline $\mathrm{H}_{2} \mathrm{~L}$ & 3384 & 1615 & 1294 & - & - & - & - & - \\
\hline$\left[\mathrm{Cr}_{2}(\mathrm{CO}) \mathrm{L}_{2}\right]$ & - & 1599 & 1380 & - & - & 1718 & 590 & 492 \\
\hline$\left[\mathrm{Mo}_{2} \mathrm{O}_{4} \mathrm{~L}_{2}\right]$ & - & 1612 & 1402 & 890,843 & 679 & - & 576 & 474 \\
\hline$\left[\mathrm{Mo}_{2} \mathrm{O}_{5}(\mathrm{CO}) \mathrm{L}_{2} \mathrm{H}_{2} \mathrm{O}\right.$ & 3423 & 1636 & 1342 & 959,880 & 627 & 1718 & 574 & 481 \\
\hline$\left[\mathrm{W}_{2} \mathrm{O}_{4} \mathrm{~L}_{2}\right]$ & - & 1620 & 1380 & 977,813 & 699 & - & 587 & 473 \\
\hline
\end{tabular}

The mass spectrum of the ligand and its complexes showed the molecular ion peak consistent with their proposed molecular formula (Table 1). The mass spectra of Schiff base and $\left[\mathrm{Mo}_{2} \mathrm{O}_{5}(\mathrm{CO}) \mathrm{L}\right] . \mathrm{H}_{2} \mathrm{O}$ complex were shown in Figure 2.

The ${ }^{1} \mathrm{H}$ NMR spectrum of ligand, $\mathrm{H}_{2} \mathrm{~L}$ (Figure 3 ) showed azomethine proton signal (s, $\mathrm{CH}=\mathrm{N}$ ) at 9.06 ppm [30] and singlet signal at $10.1 \mathrm{ppm}$ due to O-H group [31]. The multiplies aromatic ring protons appeared in the region 6.68- $7.76 \mathrm{ppm}(\mathrm{m}, 12 \mathrm{H}, \mathrm{ArH})$ [32]. Scheme 2 gave the proposed structure of $\mathrm{H}_{2} \mathrm{~L}$ ligand. The ${ }^{1} \mathrm{H}$ NMR spectra of the $\left[\mathrm{Mo}_{2} \mathrm{O}_{4}(\mathrm{~L})_{2}\right],\left[\mathrm{Mo}_{2} \mathrm{O}_{5}(\mathrm{CO}) \mathrm{L}\right] \cdot \mathrm{H}_{2} \mathrm{O}$ and $\left[\mathrm{W}_{2} \mathrm{O}_{4}(\mathrm{~L})_{2}\right]$ complexes showed downfield shift in the position of the azomethine proton $(-\mathrm{HC}=\mathrm{N})$ in comparison with that of the free ligand due to its coordination to metal atom through the azomethine nitrogen [33]. The ${ }^{1} \mathrm{H}$ NMR spectra of the complexes showed appropriate shift in phenyl protons compared with ligand as a result of complexion (Table 3) [34]. The ${ }^{1} \mathrm{H}$ NMR spectrum of $\left[\mathrm{Mo}_{2} \mathrm{O}_{5}(\mathrm{CO}) \mathrm{L}\right] \cdot \mathrm{H}_{2} \mathrm{O}$ complex showed signal attributed to two protons of hydrogen which assigned to one molecule of water [35]. In addition, the ${ }^{1} \mathrm{H}$ NMR spectra of the molybdenum and tungsten complexes showed the disappearance of the hydroxyl proton signal indicating that the ligand coordinated to the metal with proton displacement [36].

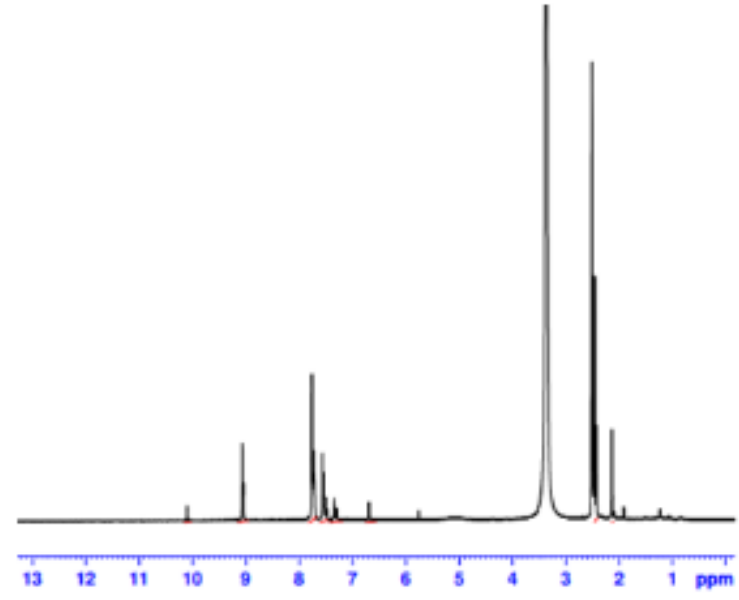

Figure3. ${ }^{1} \mathrm{H}$ NMR spectrum of ligand 


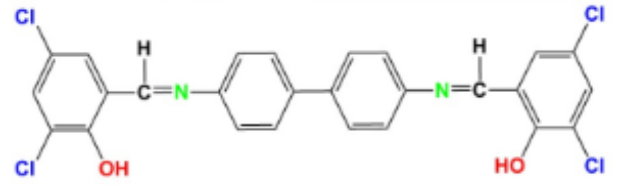

Scheme2. The proposed structure of $\mathrm{H}_{2} \mathrm{~L}$ ligand

Table3. The ${ }^{l} H$ NMR data of the synthesized ligand and its complexes

\begin{tabular}{|c|c|c|}
\hline Compound & Chemical shift & Assignment \\
\hline $\mathrm{C}_{26} \mathrm{H}_{16} \mathrm{~N}_{2} \mathrm{O}_{2} \mathrm{Cl}_{4}$ & 9.06 & $\mathrm{~s}, \mathrm{CH}=\mathrm{N}$ \\
& $7.76-6.68$ & $\mathrm{~m}, 12 \mathrm{Ar} \mathrm{H}$ \\
\cline { 2 - 3 } & 10.10 & $\mathrm{~s}, \mathrm{OH}$ \\
\cline { 2 - 3 } & 8.82 & $\mathrm{~s}$, of CH =N \\
\cline { 2 - 3 } & $8.29-6.67$ & $\mathrm{~m}, 24 \mathrm{Ar} \mathrm{H}$ \\
& $4.30-4.27$ & $\mathrm{~d}, 2 \mathrm{H}, \mathrm{H}_{2} \mathrm{O}$ \\
\hline & 8.15 & $\mathrm{~s}, \mathrm{CH}=\mathrm{N}$ \\
& $7.9-6.9$ & $\mathrm{~m}, 12 \mathrm{ArH}$ \\
\hline $\mathrm{Mo}_{2} \mathrm{H}_{28} \mathrm{C}_{27} \mathrm{O}_{8} \mathrm{H}_{16} \mathrm{~N}_{2} \mathrm{O}_{9} \mathrm{Cl}_{4}$ & 8.97 & $\mathrm{~s}, \mathrm{CH}=\mathrm{N}$ \\
\cline { 2 - 3 } & $8.69-6.95$ & $\mathrm{~m}, 24 \mathrm{Ar} \mathrm{H}$ \\
\hline
\end{tabular}

The magnetic study of the chromium complex showed paramagnetic characteristics. Magnetic measurements at $298 \mathrm{~K}$ gave effective magnetic $\left(\mu_{\text {eff }}\right)$ values of $2.93 \mathrm{BM}$. This value was close to the spin-only magnetic moment of two unpaired electrons $(2.84 \mathrm{BM})$ in low spin electronic configuration and each chromium atom existed in +2 oxidation states [37].

From spectroscopic studies and elemental analysis, it can be suggested that the $\left[\mathrm{Cr}_{2}(\mathrm{CO})_{2}(\mathrm{~L})_{2}\right]$ was a dinuclear complex with two $\mathrm{Cr}$ atoms were bridged by two carbonyl groups (Scheme 3 ). The dinuclear complex $\left[\mathrm{Mo}_{2} \mathrm{O}_{5}(\mathrm{CO}) \mathrm{L}\right] . \mathrm{H}_{2} \mathrm{O}$ might consist of two Mo atoms were bridged by one oxygen and one carbonyl group in addition to two terminal oxo groups and each molybdenum may have +6 formal oxidation states with $\mathrm{d}^{0}$ electronic configuration (Scheme 4) [38]. The two complexes $\left[\mathrm{Mo}_{2} \mathrm{O}_{4} \mathrm{~L}_{2}\right]$ and $\left[\mathrm{W}_{2} \mathrm{O}_{4} \mathrm{~L}_{2}\right]$ are dinuclear with the two $\mathrm{H}_{2} \mathrm{~L}$ moieties bound to the metal through nitrogen and oxygen atoms and each metal may have +6 formal oxidation states with $\mathrm{d}^{0}$ electronic configuration (Scheme 5).

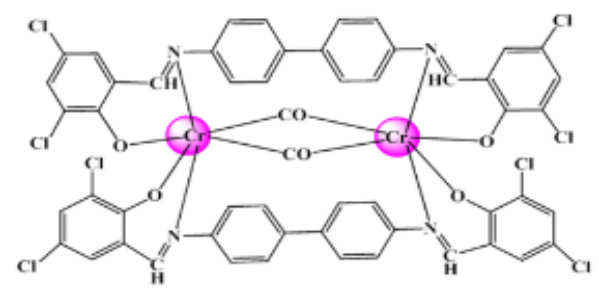

Scheme3. The structure of $\left[\mathrm{Cr}_{2}(\mathrm{CO})_{2}(L)_{2}\right]$

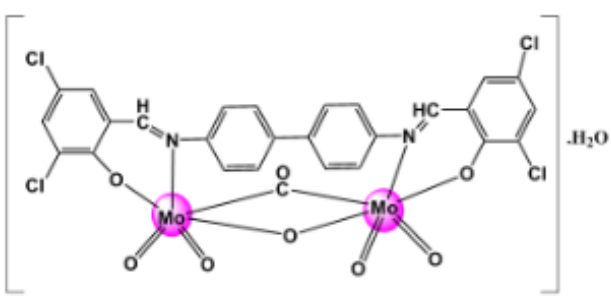

Scheme4. The structure of $\left[\mathrm{Mo}_{2} \mathrm{O}_{5}(\mathrm{CO}) \mathrm{L}\right] \cdot \mathrm{H}_{2} \mathrm{O}$

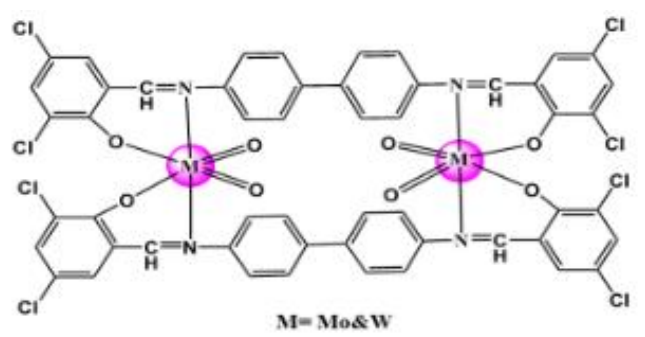

Scheme5. The structure of $\left[\mathrm{Mo}_{2} \mathrm{O}_{4}\left(\mathrm{~L}_{2}\right)\right]$ and $\left[\mathrm{W}_{2} \mathrm{O}_{4}\left(\mathrm{~L}_{2}\right)\right]$ 


\section{EleCtronic SPECTRA}

The electronic absorption studies of $\mathrm{H}_{2} \mathrm{~L}$ and its complexes were studied in DMSO solvent (Table 4). The UV-vis spectrum of the $\mathrm{H}_{2} \mathrm{~L}$ ligand displayed three absorption bands at $292 \mathrm{~nm}$ corresponded to $\pi-\pi^{*}$ and $378,460 \mathrm{~nm}$ corresponded to $\mathrm{n}-\pi^{*}$ electronic transitions [39]. Upon complexation with chromium and tungsten a hypsochromic shifts were exerted in the $\pi \rightarrow \pi^{*}$ and $n \rightarrow \pi^{*}$ electronic transitions. But in the spectra of the complexes $\left[\mathrm{Mo}_{2} \mathrm{O}_{4}\left(\mathrm{~L}_{2}\right)\right]$ and $\left[\mathrm{Mo}_{2} \mathrm{O}_{5}(\mathrm{CO}) \mathrm{L}\right] \cdot \mathrm{H}_{2} \mathrm{O}$, a bathochromic shift in the $\pi \rightarrow \pi^{*}$ electronic transitions was observed, while the $n \rightarrow \pi^{*}$ bands exhibited hypsochromic shift with a considerable change in absorbance [40].

Table4. The UV-Vis data of synthesized ligand and its complexes

\begin{tabular}{|c|c|c|}
\hline \multirow{2}{*}{ Compound } & \multicolumn{2}{|c|}{$\begin{array}{c}\text { UV - Vis data } \\
\lambda_{\max }(\mathrm{nm})\end{array}$} \\
\cline { 2 - 3 } & $\pi \rightarrow \pi^{*}$ & $\mathrm{n} \rightarrow \pi^{*}$ \\
\hline $\mathrm{H}_{2} \mathrm{~L}$ & 292 & 378,460 \\
\hline$\left[\mathrm{Cr}_{2}(\mathrm{CO})_{2} \mathrm{~L}_{2}\right]$ & 280 & 290 \\
\hline$\left[\mathrm{Mo}_{2} \mathrm{O}_{4}(\mathrm{~L})_{2}\right]$ & 294 & 366 \\
\hline$\left[\mathrm{Mo}_{2} \mathrm{O}_{5}(\mathrm{CO}) \mathrm{L}\right] \cdot \mathrm{H}_{2} \mathrm{O}$ & 294 & 320 \\
\hline$\left[\mathrm{W}_{2} \mathrm{O}_{4}(\mathrm{~L})_{2}\right]$ & 286 & 292 \\
\hline
\end{tabular}

\section{FLUORESCENCE SPECTRA}

Photoluminescence study of the ligand and its complexes were measured at room temperature in DMSO (Table 5\& Figure 4). The ligand exhibited the maximum emission bands at 442 and $479 \mathrm{~nm}$ upon excitation at $386 \mathrm{~nm}$. The emission bands of all complexes showed blue shift than that of the ligand, in which, both $\left[\mathrm{Mo}_{2} \mathrm{O}_{4}(\mathrm{~L})_{2}\right]$ and $\left[\mathrm{W}_{2} \mathrm{O}_{4}(\mathrm{~L})_{2}\right]$ displayed the maximum emission bands at 396 and $391 \mathrm{~nm}$ when excited at $292 \mathrm{~nm}$. On the other hand, $\left[\mathrm{Cr}_{2}(\mathrm{CO})_{2}(\mathrm{~L})_{2}\right]$ complex exhibited emission band at 352 $\mathrm{nm}$ upon excitation at $290 \mathrm{~nm}$. The complex $\left.\mathrm{Mo}_{2} \mathrm{O}_{5}(\mathrm{CO}) \mathrm{L}\right] \cdot \mathrm{H}_{2} \mathrm{O}$ showed no emission upon excitation at $294 \mathrm{~nm}$.

Table5. The fluorescence data of the synthesized ligand and its complexes

\begin{tabular}{|c|c|c|}
\hline \multirow{2}{*}{ Compound } & \multicolumn{2}{|c|}{$\begin{array}{c}\text { Fluorescence data } \\
\lambda_{\max }(\mathrm{nm})\end{array}$} \\
\hline & Excitation & \multicolumn{1}{c|}{ Emission } \\
\hline $\mathrm{H}_{2} \mathrm{~L}$ & 386 & $310,442,479$ \\
\hline$\left[\mathrm{Cr}_{2}(\mathrm{CO})_{2} \mathrm{~L}_{2}\right]$ & 290 & 362 \\
\hline$\left[\mathrm{Mo}_{2} \mathrm{O}_{4}(\mathrm{~L})_{2}\right]$ & 292 & 396 \\
\hline$\left[\mathrm{Mo}_{2} \mathrm{O}_{5}(\mathrm{CO}) \mathrm{L}_{2} \mathrm{H}_{2} \mathrm{O}\right.$ & 294 & 391 \\
\hline$\left[\mathrm{W}_{2} \mathrm{O}_{4}(\mathrm{~L})_{2}\right]$ & 292 \\
\hline
\end{tabular}

Figure4. Fluorescence spectra of the ligand $\left(\mathrm{H}_{2} \mathrm{~L}\right)$ and its complexes

\section{Thermal Analysis}

The thermal studies of the reported chromium, molybdenum and tungsten complexes provided further insight into the proposed structures. The detailed thermal decomposition data for complexes gave in Table 6. In addition, the structures of the investigated complexes were undertaken using thermogravimetry (T.G.) and derivative thermogravimetry (DTG) techniques (Figure 5). 
The TGA plot of $\left[\mathrm{Cr}_{2}(\mathrm{CO})_{2} \mathrm{~L}_{2}\right]$ complex decomposed in three thermal steps. The first decomposition step occurred at $95-264{ }^{\circ} \mathrm{C}$ with a weight loss of $27.95 \%$ (27.92\% calc.) was probably due to the elimination of $\left(2 \mathrm{CO}+4 \mathrm{Cl}_{2}\right)$ moieties. The second decomposition peak occurred at $269-530{ }^{\circ} \mathrm{C}$ with a weight loss of $33.89 \%$ ( $33.91 \%$ calc.), corresponding to the elimination of $\mathrm{C}_{28} \mathrm{H}_{20} \mathrm{~N}_{4}$ species. The third decomposition step occurred in the temperature range $540-800{ }^{\circ} \mathrm{C}$ with a net weight loss of $25.71 \%$ ( $25.68 \%$ calc.) attributed to the elimination of $\mathrm{C}_{24} \mathrm{H}_{8} \mathrm{O}$ species to give finally $\mathrm{Cr}_{2} \mathrm{O}_{3}$ as residue.

On the other hand, the TGA plot of $\left[\mathrm{Mo}_{2} \mathrm{O}_{4}(\mathrm{~L})_{2}\right]$ complex displayed two thermal steps in the temperature range $170-800{ }^{\circ} \mathrm{C}$. The first decomposition step at $170-561{ }^{\circ} \mathrm{C}$ with a net weight loss of $51.31 \%$ ( $51.05 \%$ calc.) corresponded to the elimination of $2 \mathrm{Cl}_{2}+\mathrm{L}$ species. The second decomposition step occurred in the range $561-800{ }^{\circ} \mathrm{C}$ with a net weight loss of $23.24 \%(23.35 \%$ calc.) consistent with elimination of $\mathrm{C}_{22} \mathrm{H}_{14} \mathrm{~N}_{2}$ species, leaving finally a residue of $2 \mathrm{MoO}_{3}+4 \mathrm{C}$ with a net weight of $25.45 \%$ ( $25.60 \%$ calc.).

The TG/DTG curves of $\left[\mathrm{Mo}_{2} \mathrm{O}_{5}(\mathrm{CO}) \mathrm{L}\right] . \mathrm{H}_{2} \mathrm{O}$ showed three decomposition steps within the temperature ranges $25-262{ }^{\circ} \mathrm{C}, 265-572{ }^{\circ} \mathrm{C}$ and $610-800{ }^{\circ} \mathrm{C}$. The weight loss of first step (Found $=13.78 \%$, Calc. $=$ $13.82 \%)$, the second step (Found. $=46.02 \%$, Calc. $=46.00 \%)$ and third step (Found $=6.16 \%$, Calc. $=$ $6.15 \%)$ were assigned to the loss of $\left(\mathrm{CO}+\mathrm{H}_{2} \mathrm{O}+\mathrm{Cl}_{2}\right), \mathrm{C}_{22} \mathrm{H}_{10} \mathrm{~N}_{2} \mathrm{OCl}_{2}$ and $\mathrm{C}_{4} \mathrm{H}_{4}$, respectively.

Table6. Thermogravimetric data of Schiff base metal complexes

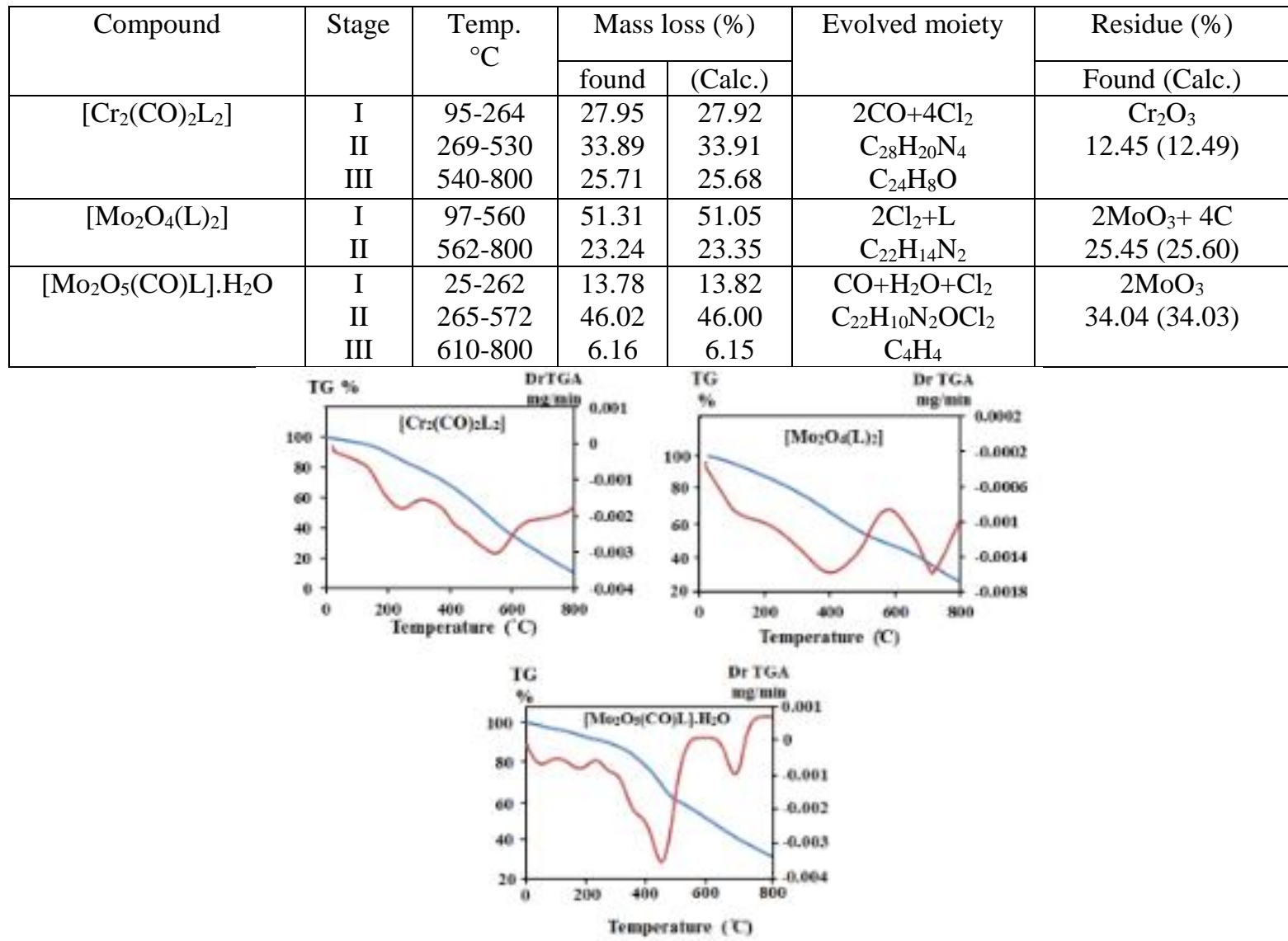

Figure5. TG-DTG thermograms of $\left[\mathrm{Cr}_{2}(\mathrm{CO})_{2}\left(\mathrm{~L}_{2}\right],\left[\mathrm{Mo}_{2} \mathrm{O}_{4}(\mathrm{~L})_{2}\right]\right.$ and $\left[\mathrm{Mo}_{2} \mathrm{O}_{5}(\mathrm{CO}) L\right] \cdot \mathrm{H}_{2} \mathrm{O}$ complexes

\section{KineTIC DATA}

The kinetic parameters for the thermal degradation of Cr, Mo and W complexes of the Schiff base $\mathrm{H}_{2} \mathrm{~L}$ were summarized in Table 7. The kinetic analysis parameters such as activation energy ( $\left.\mathrm{E}^{*}\right)$, enthalpy of activation $\left(\Delta \mathrm{H}^{*}\right)$, entropy of activation $\left(\Delta \mathrm{S}^{*}\right)$ and Gibbs free energy change of decomposition $\left(\Delta \mathrm{G}^{*}\right)$ were evaluated using Coats-Redfern (CR) [41] and Horowitz-Metzger (HM) [42,43] relationships (Figs 6-7). The entropy of activation was found to have negative values for all metal complexes which indicate that decomposition reactions proceed with a lower rate than normal ones $[44,45,46]$. The activation energies of decomposition were found to be in the range $3.53-74.32 \mathrm{~kJ} \mathrm{~mol}^{-1}$. The high values of the activation energies reflect the thermal stability of the complexes [43]. 
Spectroscopic, Structural Studies, Fluorescence and Optical Properties of Group VI Dinuclear Derivatives of $\mathrm{N}_{2} \mathrm{O}_{2}$ Schiff Base

Table7. Kinetic thermodynamic data of Schiff base metal complexes

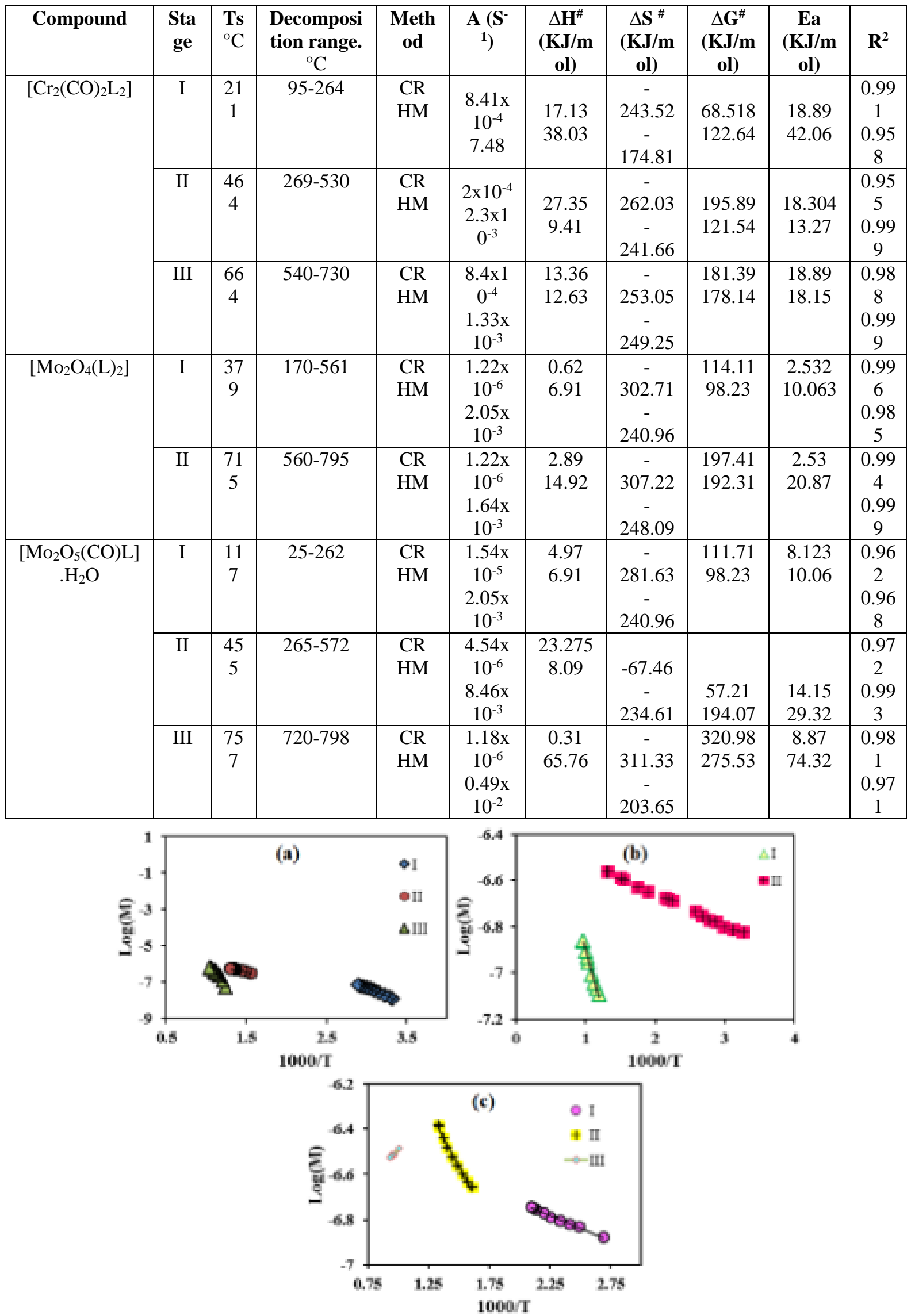

Figure6. Coats-Redfern plots of (a) $\left[\mathrm{Cr}_{2}(\mathrm{CO})_{2} \mathrm{~L}_{2}\right]$, (b) $\left[\mathrm{Mo}_{2} \mathrm{O}_{4}(\mathrm{~L})_{2}\right]$ and (c) $\left[\mathrm{Mo}_{2} \mathrm{O}_{5}(\mathrm{CO}) \mathrm{L}\right] . \mathrm{H}_{2} \mathrm{O}$ complexes (log $\left.M=\log \left[\log \left\{W_{\infty}\left(W_{\infty}-W\right)^{-1}\right\} T^{-2}\right]\right)$. 

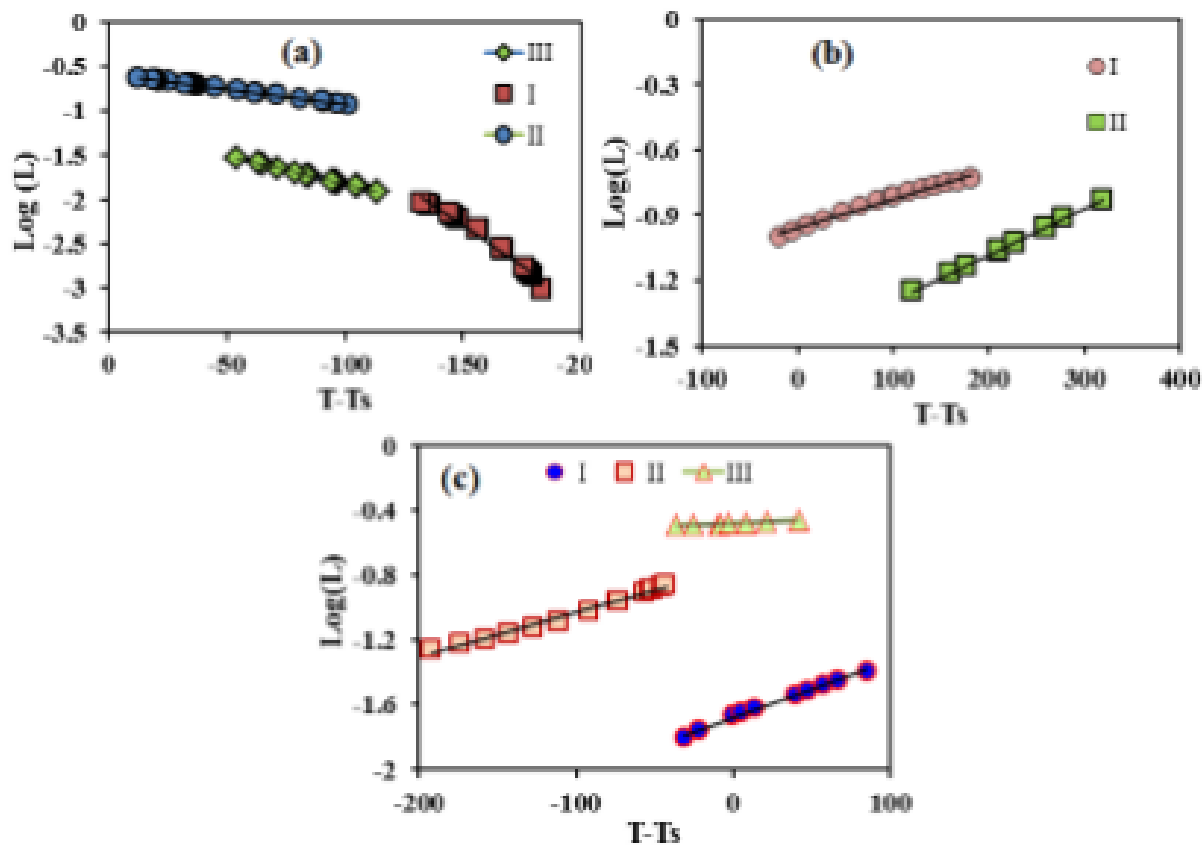

Figure7. Horowitz-Metzger plots of (a) $\left[\mathrm{Cr}_{2}(\mathrm{CO})_{2} \mathrm{~L}_{2}\right],(b)\left[\mathrm{Mo}_{2} \mathrm{O}_{4}(\mathrm{~L})_{2}\right]$ and (c) $\left[\mathrm{Mo}_{2} \mathrm{O}_{5}(\mathrm{CO}) L\right] \cdot \mathrm{H}_{2} \mathrm{O}$ complexes $(\log L=\log [\log \{W \infty(W \infty-W)-1\}])$

\section{OPTICAL Properties}

The optical band gap (Eg) was determined from the electronic spectra of the complexes by using the following relation $\alpha$ hv $=\mathrm{A}$ (hv- $\mathrm{Eg}$ ) $\mathrm{m}$, where $\mathrm{m}$ is equal to $1 / 2$ and 2 for indirect and direct transition respectively, $A$ is an energy independent constant and $\alpha$ was calculated from the relation $\alpha=1 / \mathrm{d} \ln A$ (where, $\mathrm{A}$ is the absorbance and $\mathrm{d}$ is the width of the cell) [47]. The plot $(\alpha \mathrm{hv})^{2} \mathrm{vs}$. ho indicated that the type of electronic transition was direct (Figure 8). The values of band gap ( $\mathrm{Eg})$ for $\left[\mathrm{Cr}_{2}(\mathrm{CO})_{2}(\mathrm{~L})_{2}\right]$, $\left[\mathrm{Mo}_{2} \mathrm{O}_{4}(\mathrm{~L})_{2}\right],\left[\mathrm{Mo}_{2} \mathrm{O}_{5}(\mathrm{CO}) \mathrm{L}\right] . \mathrm{H}_{2} \mathrm{O}$ and $\left[\mathrm{W}_{2} \mathrm{O}_{4}(\mathrm{~L})_{2}\right]$ were found to be 3.51, 2.91, 3.49 and 3.52, respectively. This indicated that these complexes could be used as promising materials for optoelectronic devices [48].

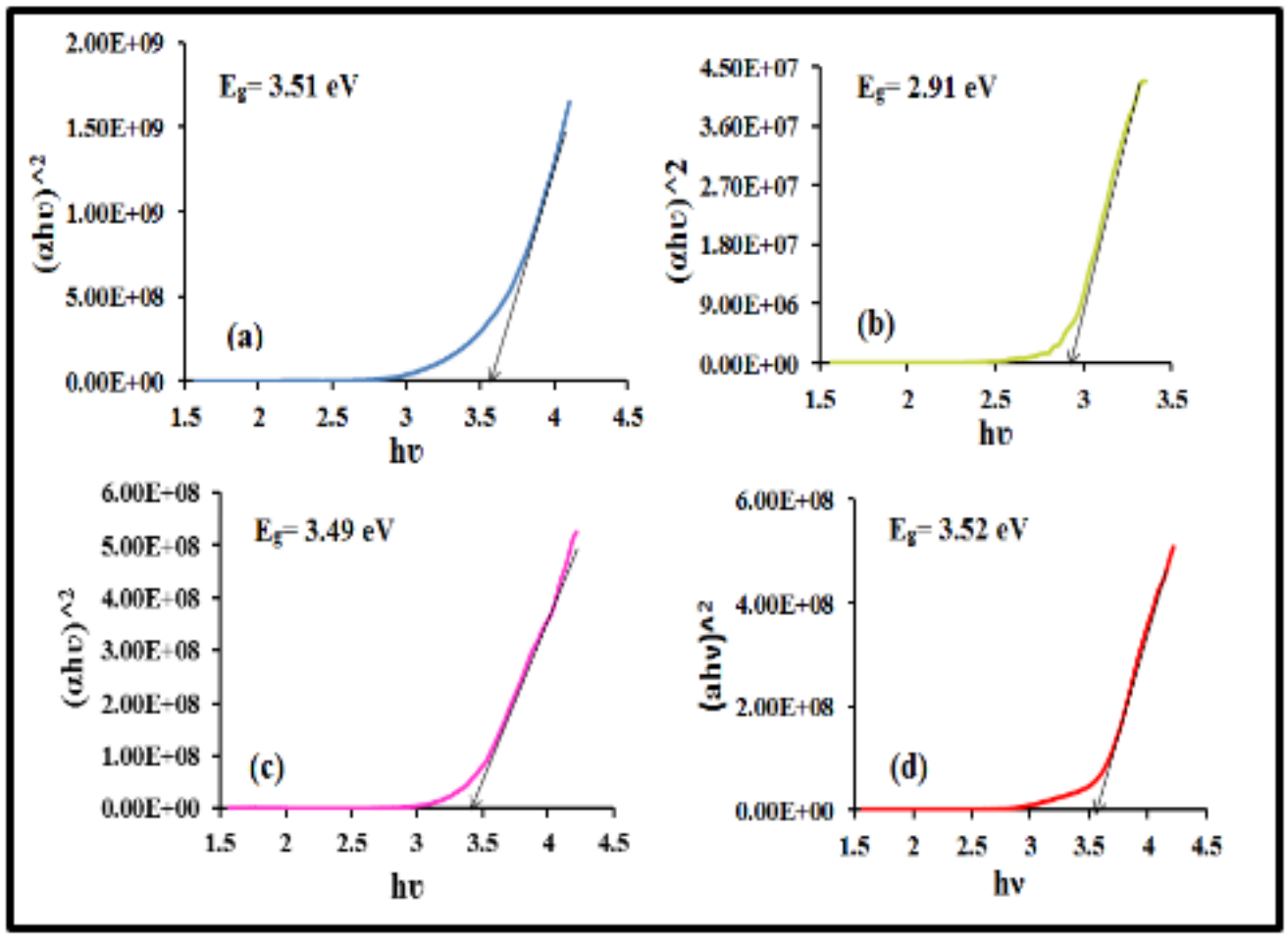

Figure8. Optical band gap of (a) $\left[\mathrm{Cr}_{2}(\mathrm{CO})_{2}(\mathrm{~L})_{2}\right]$, (b) $\left[\mathrm{Mo}_{2} \mathrm{O}_{4}(\mathrm{~L})_{2}\right]$, (c) [Mo $\left.\mathrm{M}_{5}(\mathrm{CO}) L\right] . \mathrm{H}_{2} \mathrm{O}$, (d) $\left[\mathrm{W}_{2} \mathrm{O}_{4}(\mathrm{~L})_{2}\right]$. 


\section{CONCLUSION}

Four new complexes were synthesized from the reactions of $\mathrm{M}(\mathrm{CO})_{6}(\mathrm{M}=\mathrm{Cr}$, Mo, W) with the 6,6'(([1,1'biphenyl $] 4,4$ 'diylbis(azaneylylidene))bis(methaneylylidene))bis(2,4dichlorophenol) $\quad\left(\mathrm{H}_{2} \mathrm{~L}\right)$ Schiff base in THF. The dinuclear carbonyl complex $\left[\mathrm{Cr}_{2}(\mathrm{CO})_{2}(\mathrm{~L})_{2}\right]$ and two oxo complexes $\left[\mathrm{Mo}_{2} \mathrm{O}_{4}(\mathrm{~L})_{2}\right]$ and $\left[\mathrm{W}_{2} \mathrm{O}_{4}(\mathrm{~L})_{2}\right]$ formed under sunlight irradiation. In air, the corresponding reaction gave the oxocarbonyl complex $\left[\mathrm{Mo}_{2} \mathrm{O}_{5}(\mathrm{CO}) \mathrm{L}\right] \cdot \mathrm{H}_{2} \mathrm{O}$. Analytical and spectral data revealed that $\mathrm{H}_{2} \mathrm{~L}$ was coordinated as tetradentate ligand through two imine nitrogen and two deprotonated phenolic oxygen atoms with 2:2 stoichiometries. The magnetic measurements of the synthesized complexes showed all the complexes were diamagnetic except $\left[\mathrm{Cr}_{2}(\mathrm{CO})_{2}(\mathrm{~L})_{2}\right]$ complex was paramagnetic. The activation thermodynamic parameters, such as activation energy, enthalpy, entropy and Gibbs free energy change of complexes decomposition were calculated from TG curves. Furthermore, these complexes exhibited fluorescence properties and could be used as photoactive materials. The optical band gap of the isolated complexes indicated semi-conductivity nature of these compounds.

\section{REFERENCES}

[1] Luo, X.F., Hu X., Zhao, X.Y., Goh, S.H., Li, X.D., Miscibility and interactions in blends and complexes of poly(4-methyl-5-vinylthiazole) with proton-donating polymers, Polymer, 44 (2003), 5285-5291

[2] Baumgrass,_R., Weiwad, M., Erdmann, F., Liu, J.O., Wunderlich, D., Grabley, S., Fischer, G., Reversible inhibition of calcineurin by the polyphenolic aldehyde gossypol, J. Bio. Chem., 276 (2001), 47914-47921.

[3] Hunter, C.A., Self-Assembly of Molecular-Sized Boxes, Angew Chem. Int. Ed. Engl., 34 (1995), 1079-1081.

[4] Stang, P.J., Cao, D.H., Saito, S., Arif, A.M., Self-Assembly of Cationic, Tetranuclear, Pt (II) and Pd (II) Macrocyclic Squares. $x$-ray Crystal Structure of $\left[\mathrm{Pt} 2+(\right.$ dppp $)\left(4,4^{\prime} \text {-bipyridyl). chtdot. 2-OSO } \mathrm{OS}_{2} \mathrm{CF}_{3}\right]_{4}$, J. Am. Chem. Soc., 117 (1995), 6273-6283.

[5] Wu, I.Y., Lin, J.T., Luo, J., Sun, S.S., Li, C.S., Lin, K.J., Tsai, C., Hsu, C.C., Lin, J.L., Syntheses and Reactivity of Ruthenium $\sigma$-Pyridylacetylides, Organomettalics, 16 (1997), 2038-2048.

[6] Abu-Hussen, A.A., Synthesis and spectroscopic studies on ternary bis-Schiff-base complexes having oxygen and/or nitrogen donors, J. Coord. Chem., 59 (2006), 157-176.

[7] Karthikeyan, M.S., Parsad, D.J., Poojary, B., Bhat, K.S., Holla, B.S., Kumari, N.S., Synthesis and biological activity of Schiff and Mannich bases bearing 2, 4-dichloro-5-fluorophenyl moiety, Bioorg. Med. Chem., 14 (2006) 7482-7489.

[8] El-Medani, S.M., Structural studies of some chromium, molybdenum and tungsten complexes of $N$ salicylidene-2- hydroxyaniline, J. Coord. Chem., 57 (2004), 115-122.

[9] El-Medani, S.M., Reactions of chromium, molybdenum and tungsten carbonyls with a tetradentate Schiff base, J. Coord. Chem., 57(2004), 497-507.

[10] El-Medani, S.M., Aboaly, M.M., Abdalla, H.H., Ramadan, R.M., Reactions of group 6 metal carbonyls with salicylaldehyde hydrazone, Spectroscopy Lett., 37 (2004), 619-632.

[11] Collman, J., Hegedus, L.S., Principles and Application of Organotransition Metal Chemistry, University Science Book, CA, 1980.

[12] Zhao, J., Zhao, B., Liu, J., Xu, W., Wang, Z., Spectroscopy study on the photochromism of Schiff Bases N,N'bis(salicylidene)-1,2-diaminoethane and $\mathrm{N}, \mathrm{N}^{\prime}$-bis(salicylidene)-1,6 hexanediamine, Spectrochim. Acta A, 57 (2001), 149-154.

[13] Ali, S.A., Soliman, A.A., Aboaly, M.M., Ramdan, R.M., chromium, molybdenum and ruthenium complexes of 2-Hydroxyacetophenone Schiff bases, J. Coord. Chem., 55 (2002), 1161-1170.

[14] Soliman, A.A., El-Medani, S.M., Ali, O.A.M., Thermal study of chromium and molybdenum complexes with some nitrogen and nitrogen-oxygen donors ligands, J. Ther. Analy. and Calor., 83 (2006), 385-392.

[15] El-Medani, S.M., Ali, O.A.M., Ramadan, R.M., Photochemical reactions of group 6 metal carbonyls with $\mathrm{N}$-salicylidene-2-hydroxyaniline and bis (salicylaldehyde)phenylenediimine, J. Mol. Struct., 738 (2005), 171-177.

[16] Silva da, C., Silva da, D., Modolo, L., Alves, R., Schiff bases: A short review of their antimicrobial activities, J. Ad. Res., 2 (2011), 1-8.

[17] Yang, X., Wang, Q., Huang, Y., Fu, P., Zhang, J., Zeng, R., Synthesis, DNA interaction and antimicrobial activities of copper (II) complexes with Schiff base ligands derived from kaempferol and polyamines, Inorg. Chem. Com., 25 (2012), 55-59.

[18] Kumar, S., Dhar, D.N., Saxena, P.N., Applications of metal complexes of Schiff bases - a review, J. Sci. Ind. Res., 68 (2009), 181-187. 
[19] Sanatkar, T.H., Khorshidi, A., Sohouli, E., Janczak, J., Synthesis, Crystal Structure, and Characterization of Two $\mathrm{Cu}(\mathrm{II})$ and $\mathrm{Ni}(\mathrm{II})$ Complexes of a Tetradentate $\mathrm{N}_{2} \mathrm{O}_{2}$ Schiff Base Ligand and Their Application in Fabrication of a Hydrazine Electrochemical Sensor, Inorg. Chim. Acta., 506 (2020), 119537-119548.

[20] Abd El-Razek , S.E., El-Gamasy, S.M., Hassan, M., Abdel-Aziz, M.S., Nasr, S.M.,Transition Metal Complexes of a Multidentate Schiff Base Ligand Containing Guanidine Moiety: Synthesis, Characterization, Anti-Cancer Effect, and Anti-Microbial Activity, J. Mol. Struct., 1203 (2020), 127381-127390.

[21] Ali, O.A.M., Khalil, M.M.H., Attia, G.M., Ramadan, R.M., Group VI Dinuclear Oxo Metal Complexes of Salicylideneimine-2-Anisole Schiff Base, Spectroscopy Lett., 36 (2003), 71-82.

[22] Mohamed, R.G., Elantabli, F.M., Helal, N.H., El-Medani, S.M., New Group 6 Metal Carbonyl Complexes with 4,5-Dimethyl-N,N-Bis(Pyridine-2-YlMethylene)Benzene-1,2-Diimine Schiff Base: Synthesis, Spectral, Cyclic Voltammetry and Biological Activity Studies, Spectrochim. Acta A Mol. Biomol. Spectrosc., 141 (2015), 316-326.

[23] Guo, Y., Hu, X., Zhang, X., Pu, X., Wang, Y.,The Synthesis of a Cu(Ii) Schiff Base Complex Using a Bidentate $\mathrm{N}_{2} \mathrm{O}_{2}$ Donor Ligand: Crystal Structure, Photophysical Properties, and Antibacterial Activities, RSC Adv., 9 (2019), 41737-41744.

[24] Soliman, A.A., Ali, S.A., Marei, A.H., Nassar, D.H., Synthesis, characterization and biological activities of some new chromium, molybdenum and tungsten complexes with 2,6-diaminopyridine, Spectrochim. Acta A, 89 (2012), 329-332.

[25] Khalil, M.M.H., Mohamed, H.A., El-Medani S.M., Ramadan, R.M., New group 6 metal carbonyl derivatives of 2-(2-pyridyl) benzimidazole: synthesis and spectroscopic studies, Spectrochim. Acta A, 59 (2003), 13411347.

[26] Taher, M.A., Jarelnabbi, S.E., Bayoumy, B.E., El-Medani, S.M., Ramadan, R.M., Synthesis and Spectroscopic Studies of Some New Molybdenum, Tungsten, and Ruthenium Carbonyl Derivatives of 2Hydroxymethylpyridine, Inter. J. Inorg. Chem., 2010 (2010), 1-6.

[27] Garin, A.B., Rakarić, D., Andrić, E.K., Kosanović, M.M., Balić, T., Perdih, F., Synthesis of Monosubstituted Dipicolinic Acid Hydrazide Derivative and Structural Characterization of Novel Co(III) and Cr(III) Complexes, Polyhedron, 166 (2019), 226-232.

[28] Ali, O.A.M., El-Medani, S.M., Ahmed, D.A., Nassar, D.A., Metal carbonyl complexes with Schiff bases derived from 2-pyridinecarboxaldehyde: Syntheses, spectral, catalytic activity and antimicrobial activity studies, J. Mol. Struct., 1074 (2014), 713-722.

[29] Ali, S.A., Soliman, A.A., Marei, A.H., Nassar, D.H., Synthesis and characterization of new chromium, molybdenum and tungsten complexes of 2-[2-(methylaminoethyl)] pyridine, Spectrochim. Acta A, 94 (2012), 164-168.

[30] Sedighipoor, M., Kianfar, A.H., Mohammadnezhad, G., Görls, H., Plass, W., Momtazi-Borojeni, A.A., Abdollahi, E., Synthesis, Crystal Structure of Novel Unsymmetrical Heterocyclic Schiff Base Ni(II)/V(IV) Complexes: Investigation of DNA Binding, Protein Binding and in Vitro Cytotoxic Activity, Inorg. Chim. Acta, 488 (2019), 182-194.

[31] Al- shemary, R.K., Shafiq, Z.A., Synthesis, Charactrization and biologycal activity for binuclear complexes $\mathrm{Co}$ ( II ), $\mathrm{Cu}$ ( II ), $\mathrm{Ni}$ ( II ), $\mathrm{Mn}$ ( II ) and $\mathrm{Hg}$ ( II ) with Schiff base ligand type $\mathrm{N}_{2} \mathrm{O}_{2}$, As. J. Phar.Sci \& Tech, 5 (2005), 172-178.

[32] Sedighipoor, M., Kianfar, A.H., Mohammadnezhad, G., Görls, H., Plass, W.,Unsymmetrical Palladium(II) N,N,O,O-Schiff Base Complexes: Efficient Catalysts for Suzuki Coupling Reactions, Inorg. Chim. Acta, 476 (2018), 20-26.

[33] Datta, P., Sardar, D., Mukhopadhyay, A.P., López-Torres, E., Pastor, C.J., Sinha, C., Group-6 Metal Carbonyl Complexes of Pyridylbenzoxazole and Pyridylbenzothiazole: Synthesis, Structure, Electrochemistry, Photophysical Property and DFT Calculations, J. Organomet. Chem., 696 (2011), 488495.

[34] Khalil, M.M.H., Al-Seif, F.A., Group 6 Metal Carbonyl Complexes of 3'H-Spiro[Indole-3,2'[1,3]Benzothiazole-2(1H)]-One, J. Saudi. Chem. Soc., 14 (2010), 33-39.

[35] Abdallah, S.M., Zayed, M.A., Mohamed, G.G., Synthesis and Spectroscopic Studies of New tetradentate Schiff base and its coordition compounds of NOON donor atoms and their antibactrial and antifungal activity, Arabian J. Chem., 3 (2010), 103-113.

[36] Abdel-Rahman, L.H., Abu-Dief, A.M., El-Khatib, R.M., Abdel-Fatah, S.M., Some New Nano-Sized Fe(II), Cd(II) and Zn(II) Schiff Base Complexes as Precursor for Metal Oxides: Sonochemical Synthesis, Characterization, DNA Interaction, in Vitro Antimicrobial and Anticancer Activities, Bioorg. Chem., 69 (2016), 140-152. 
[37] Mohamed, H.A., Photochemical reactions of chromium, molybdenum and tungsten hexacarbonyls with dimethylglyoxime, J. Mol. Struct., 784 (2006), 254-258.

[38] Ali, O.A.M., Synthesis and characterization of molybdenum complexes with salicylideneimine-2-anisole and certain heterocyclic nitrogen ligands, J. Coord. Chem., 60 (2007), 1213-1221.

[39] Salman, Y., Barlas, F.B., Yavuz, M., Kaya, K., Timur, S., Telli, F.Ç., Synthesis, characterization and biological application of dinuclear Cu(II) complexes of Schiff base ligands of galactochloralose and $\alpha$ chloralose, Inorg. Chim. Acta, 483 (2018), 98-105.

[40] Ali, O.A.M., Abu Al-Nasr, A.K., Ramadan, R.M., Synthesis and spectroscopic and structural studies of ruthenium carbonyl derivatives of $N$-salicylidene-2 hydroxyaniline Schiff base, J. Taibah Uni. Sci., 8 (2014), 258-264.

[41] Coats, A.W., Redfern, J.P., Kinetic Parameters from Thermogravimetric Data, Nature, 201 (1964), 68-69. 42. Horowitz, H.W., Metzger, G.A., A New Analysis of Thermogravimetric Traces, Analy. Chem., 35 (1963), 1464-1468.

[42] Shukla, S., Mishra, A.P., Non-isothermal degradation-based solid-state kinetics study of copper (II) Schiff base complex, at different heating rates, J. Therm. Analy. Calorim., 107 (2012), 111-117.

[43] Frost, A.A., Pearson, R.G., Kinetics and Mechanism - A Study of Homogeneous Chemical Reactions, John Wiley, New York, 73 (1961), 719-719.

[44] Sadeek, S.A., El-Shwiniy, W.H., Preparation, structure and microbial evaluation of metal complexes of the second generation quinolone antibacterial drug lomefloxacin, J. Mol. Struct., 981 (2010), 130-138. 46. Mahmoud, W.H., Mohamed, G.G., El-Dessouky, M.M.I., Synthesis, structural characterization, in vitro antimicrobial and anticancer activity studies of ternary metal complexes containing glycine amino acid and the anti-inflammatory drug lornoxicam, J. Mol. Struct., 1082 (2015), 12-22.

[45] Karipcin, F., Dede, B., Caglar, Y., Hur, D., Ilican, S., Caglar, M., Sahin, Y., A new dioxime ligand and its trinuclear copper(II) complex: Synthesis, characterization and optical properties, Opt. Commu., 272 (2007), 131-137.

[46] Rashad, M.M., Hassan, A.M., Nassar, A.M., Ibrahim, N.M., Mourtada, A., A new nano-structured Ni(II) Schiff base complex: synthesis, characterization, optical band gaps, and biological activity, Apply Phys. A, 117 (2014), 877-890.

Citation: Doaa A. Nassar, et.al, "Spectroscopic, Structural Studies, Fluorescence and Optical Properties of Group VI Di nuclear Derivatives of $\mathrm{N}_{2} \mathrm{O}_{2}$ Schiff Base”, International Journal of Advanced Research in Chemical Science, 7(7), pp. 1-12. DOI: https:// doi.org/10.20431/2349-0403.0707001

Copyright: (c) 2020 Authors, this is an open-access article distributed under the terms of the Creative Commons Attribution License, which permits unrestricted use, distribution, and reproduction in any medium, provided the original author and source are credited. 